\title{
Biotech in Hong Kong: How Biologist-Entrepreneurs Pursued "Hong Kong's Bioscience Dream"
}

\author{
Christine Y. L. Luk
}

Received: $\mathbf{\square}$ / Accepted:

(C) 2016 Ministry of Science and Technology, Taiwan

\begin{abstract}
This article aims to put Hong Kong on the map of East Asia's biotech studies by identifying the major themes of biotech innovation specific to the citystate's colonial past and postcolonial present and future. I provide evidence of a concerted effort led by biologist-entrepreneurs to promote the biotech industry in postcolonial Hong Kong. Through assessing scientific literature, media representations, business strategies, and programmatic visions of key scientist-entrepreneurs in Hong Kong's biotech enterprise, I highlight how factors such as local history and geopolitical considerations shape the emerging "Hong Kong's bioscience dream." Using the recent discovery of a new recombinant anticancer drug, pegylated human recombinant arginase (BCT-100), as a case in point, I explore how biotech research and applications are marketed and interpreted in relation to Hong Kong's unique historical, political, and cultural context, thus making it distinct from other Asian Tigers. My analysis of the featured recombinant drug reveals a set of uniquely Hong Kong-centered cultural meanings attributed to biopharmaceutical research and benefits. This case reflects how genetic engineering and biotech research are configured and imagined within the context of the postcolonial Hong Kong Special Administrative Region.
\end{abstract}

Keywords Hong Kong SAR · biotech · pharmaceutical · biologists · entrepreneurs · cancer therapy $\cdot$ BCT-100

\footnotetext{
Acknowledgments A previous version of this article was presented at the School of Modern Languages and Cultures at the University of Hong Kong. I thank the audience for raising many interesting questions to help turn my talk into a more publishable paper. The manuscript benefited from comments and conversations with Ruben Gonzalez-Vicente, Ann Hibner Koblitz, and Graeme Lang. I am grateful to two anonymous reviewers for their critical but constructive suggestions to help improve the quality of this article. I also appreciate the assistance from the editorial office, specifically Chia-Ling Wu, Wen-Hua Kuo, and Yen Ke.
}

C. Y. L. Luk

Hong Kong Institute for the Humanities and Social Sciences, the University of Hong Kong, Hong Kong e-mail: chrisluk@hku.hk 


\section{Introduction: Biotech in Hong Kong}

In 2012 a sponsored supplement titled "Hong Kong in Focus: Asia's Research Hub" (Sanders 2012) appeared in the influential magazine Science. This article, produced by the Science/AAAS Custom Publishing Office with the support of the Hong Kong Biotechnology Organization, showcased the multitude of research and investment opportunities that Hong Kong has to offer in the high-tech industry and particularly in the biotech arena. It commences with an overview section, with quotations from Chun-ying Leung, chief executive of the Hong Kong Special Administrative Region (SAR) government, saying that "biotech is an emerging sector that has been designated a key industry for development" and that "the Hong Kong Government is determined to promote biotech as a key industry" (Sanders 2012: 1640). The overview section also features input from Regina Ip, widely known among Hong Kong residents as the former secretary for security in Tung Chee-hwa's administration who stepped down after her controversial handling of the national security legislation case in 2003.

In many ways the sponsored supplement is public relations prose, and the fact that it appeared in a respected academic publication reflects the sophisticated marketing campaign of the city-state to reach out to the global scientific community. Albert Yu, an academic biologist turned entrepreneur who founded the Hong Kong Biotechnology Organization, explicitly articulates the agenda of the sponsored supplement: "We want to show the international community that Hong Kong is fully committed to building and growing this [biotech] industry and that our government, academia, and industry are all taking proactive roles in contributing to biotech" (Sanders 2012: 1641). At the center of this quotation is not a reference to Hong Kong's technological capabilities or its research and development (R\&D) infrastructure but, more important, a declaration of the government's commitment to biotech. In other words, what $\mathrm{Yu}$ wanted to emphasize, and what this sponsored supplement wanted to communicate to the international audience, is the city-state's unreserved support and strategic interests in biotech.

The declaration of Hong Kong's commitment to supporting biotech taps into a knowledge gap in the STS literature on biotech and biopolitics in East Asia. Informed readers familiar with Asia's biotech would notice the absence of Hong Kong among the leading players of biotech innovation and development in the region. Compared with the other three Asian Tigers (Singapore, South Korea, and Taiwan), Hong Kong is the only advanced economy in East Asia that has not been associated with the pinnacle of biotech modernity: South Korea is renowned for its stem cell research and clinical R\&D facilities, Taiwan has a substantial number of small and mediumsized enterprises focusing on mid- and downstream biotech marketing and sales services, and Singapore spent years building its life science megaproject known as Biopolis. These efforts, coordinated by the developing states in East Asia, attract scholarly interests in the social, anthropological, historical, and ethical dimensions of East Asia's biotech infrastructure. Jennifer Liu (2012) examines the connection between stem cell research and identity politics in Taiwan; Charis Thompson (2010) gives a fascinating comparative ethnography of stem cell laboratories in Singapore and South Korea; Aihwa Ong (2010) probes into the ethics of blood banking in Singapore; Catherine Waldby (2009) writes about Singapore's Biopolis, while Axel Gelfert (2013) analyzes the pre-Biopolis media and policy discourses; and Joseph 
Wong (2011) critically compares the divergent policy and governance issues of biotech in South Korea, Singapore, and Taiwan.

Meanwhile, Hong Kong has received very little scholarly attention. For example, Wong's above-mentioned 2011 study noticeably excludes Hong Kong from its analysis of challenges to biotech governance for the three Asian Tigers. The edited volume Asian Biotech (Ong and Chen 2010) comprises an impressive list of essays exploring bioethical issues in Asian countries such as India, China, South Korea, Singapore, Taiwan, Japan, and Thailand, with no mention of Hong Kong. This, however, does not mean that one cannot locate literature pertaining to the bioindustry and bioeconomy in Hong Kong. But most of the existing writings tend to subjugate biotech under the broader category of R\&D policy making (Berger and Lester 1997), innovation and technology management (Fuller 2010), and innovation system analysis (Baark and Sharif 2006; Sharif 2010). The few articles that offer an exclusive focus on biotech (Baark 2005; Wong 2010) generally identify a lack of government commitment to biotech development in the previous decades.

In light of this literature gap, this article attempts to contribute to the growing body of literature on Asian biotech by providing a focused discussion on the emerging biotech discourse in Hong Kong. I argue that the recent biotech initiative in Hong Kong is well worth examining since Hong Kong is an understudied affluent state in East Asia that is leveraging its relationship with the world's second largest economy.

The article proceeds as follows: Section 2 reviews literature that highlights the dearth of scholarly interests in Hong Kong's biotech. To seek insights into Hong Kong's late entry to the biotech game among the developing East Asian states, I draw upon relevant literature to give evidence that a shift from the paradigm of laissez-faire is gradually taking place in postcolonial Hong Kong. Section 3 visits the previous biotech program in the late colonial decades under the leadership of the Hong Kong Institute of Biotechnology (HKIB) and the Biotechnology Research Institute (BRI), to bring out the differences of the postcolonial biotech initiative. Section 4 gives an in-depth analysis of the making of the anticancer drug pegylated human recombinant arginase $(\mathrm{BCT}-100)^{1}$ by exploring the three means that three Hong Kong biologist-entrepreneurs and media workers utilized to cultivate public enthusiasm for the new drug. I argue that the Hong Kong mainstream newspapers and magazines put the drug on a pedestal by exploiting the identity politics of the Hong Kong populace. I suggest that the key to understanding the media campaign and the public expectation of the drug is the relationship between techniques of life sciences and political discourses. Section 5 compares and contrasts the colonial biotech initiative

\footnotetext{
${ }^{1}$ Pegylated denotes the covalent attachment of the polymer (polyethylene glycol, or PEG) to the molecular surface of arginase, an enzyme that metabolizes arginine, an amino acid necessary for the survival of both normal and tumor cells. Since arginine is produced by normal but not tumor cells (especially but not exclusively hepatoma), the drug essentially depletes intracellular arginine to inhibit the proliferation of hepatocellular carcinoma (liver cancer cells). The registered name of the drug, BCT-100, derives from the first three initials of the name of the biotech company, Bio-Cancer Treatment International Ltd., cofounded by the three Hong Kong scientists who codiscovered this drug. The National Cancer Institute Drug Dictionary names it "pegylated recombinant human arginase I BCT-100" (code name PEG-BCT-100; www .cancer.gov/drugdictionary?cdrid $=657226$, accessed 10 March 2016). This article uses the name BCT-100 because it is the term used regularly in clinical trials (NIH 2009, 2010), media reports (Sanders 2012), and scientific literature (Mussai et al. 2015) by the three Hong Kong scientists who codiscovered the drug (UGC 2007a; Capital Weekly 2013).
} 
centered on the antimalaria vaccine $\mathrm{TBV} 25 \mathrm{H}$ with the postcolonial wave of biotech revolution that rests upon the new anticancer drug BCT-100, in order to critically evaluate the claims of biomedical benefits and innovativeness surrounding BCT-100 vis-à-vis that of TBV25H, a Hong Kong-manufactured therapeutic vaccine developed in the premillennium decades. ${ }^{2}$ Section 5 also discusses how other biologist-entrepreneurs leveraged the Chinese market force by turning scandalous health problems in China into profitable business opportunities in Hong Kong. Section 6 discusses the significance of the research findings within the framework of "communities of fate" outlined by Ong (2010). I summarize the moral economy of "Hong Kong's bioscience dream" 3 by relating its core themes to the three forms of biopolitical communalism articulated in Ong's framework. By exploring ways in which life science innovation shaped the collective fates of the city's populations, I seek a better understanding of the ways in which biologist-entrepreneurs help life science applications take root in postcolonial Hong Kong.

\section{Biotech in Hong Kong: A Latecomer among the Late-Developing East Asian States}

The dearth of literature featuring Hong Kong's biotech reflects a scholarly view regarding the policy and infrastructure of science and technology in Hong Kong. Comparing the biotech industrial policies of Hong Kong and Singapore, Lai Si Tsui-Auch asserts, "The biotechnology industry of Hong Kong remains at the "infancy stage,' whereas that of Singapore has achieved significant milestones in obtaining patents and commercializing products" (2000: 4). Echoing Tsui-Auch's analysis, Gelfert adds: "Whereas the Hong Kong government made no plan and program for biotechnology_partly because pre-1997 governments had little incentive to develop long-term high-tech capabilities, given the foreseeable takeover of Hong Kong by China - the Singapore government set up science parks to foster frequent exchanges and linkages between industry, academia, and government" (2013: 105). Although both Tsui-Auch and Gelfert are based in Singapore, their perspectives are generally in line with the viewpoints supplied by Hong Kong-based scholars. Assessing the weak biotech industry in post-1997 Hong Kong, Erik Baark described Hong Kong as "the 'odd-one-out' among the successful Asian newly industrialized economies" in light of its meager public R\&D expenditure compared with other advanced economies in East Asia (2005: 10). Moreover, Baark gives a stern assessment of the Hong Kong govern-

\footnotetext{
2 TBV25H stands for "transmission-blocking vaccine based on the protein Pfs 25 with a histidine tag." Transmission-blocking vaccine refers to the vaccine interrupting the development of drug-resistant malaria parasites in the bloodstream, which acts to "block" the "transmission" of parasites from one individual to another. Pfs 25 and histidine tags are procedures to improve the quality of the previous generation of transmission-blocking vaccines, which suffered from the problem of protein degradation. Pfs (Plasmodium falciparum) 25 is a $25-\mathrm{kDa}$ cysteine-rich protein, a type of recombinant protein with $\mathrm{N}$-terminus degradation, while histidine tag refers to the technique of histidine-tagged nickel-binding purification, which is used to increase the protein-binding capacity of aminopeptidase. The immunogenicity (immunity-generating ability) of TBV25H is experimentally shown to supersede that of TBV5 by a substantial degree (Kaslow and Shiloach 1994).

3 “Hong Kong's bioscience dream" (香港生科夢) is the caption of a local media report featuring Albert Yu and his team (Capital 2002).
} 
ment's systematic lack of commitment to building the necessary infrastructure to support biotech: "With reference to systemic failures, the Hong Kong commitments have been weak both in terms of financial resources and in terms of the creation of infrastructure. Hong Kong biotechnology continues to suffer from the small share of support from public as well as private sources" (14). His analysis of a series of biotech initiatives put forth by the Hong Kong colonial government in the 1990s is further assessed in section 3 of this article. These examples support the contention that scholars from both Singapore and Hong Kong basically agree that Hong Kong had no serious biotech policy or infrastructure in place from the pre-1997 colonial period to the post-1997 special administrative period. It is this dim view of Hong Kong's science and technology affairs that contributes to the knowledge gap in the STS literature.

One of the common reasons given for the Hong Kong government's reluctance to support biotech is its doctrine of laissez-faire, or "positive noninterventionism," where the government recedes to a minimalist style of governance while giving market forces the latitude to take control of industrial policy making. The laissez-faire policy rationale is underscored by Baark (2005) in his attempt to explain why the Hong Kong government did not take any significant action in the 1990s. Likewise, Tsui-Auch describes the Hong Kong's industrial policy practice as "functional" where "the state confines itself to stimulating an ideal market by fulfilling general economic functions" (2000: 2). Therefore, both Baark and Tsui-Auch seem to attribute the cause of Hong Kong's lackadaisical undertaking in biotech to a policy void. The Hong Kong government is hamstrung by a lack of policy justification for public spending, let alone supporting new technologies such as biotech.

However, more recent studies have begun to explore the limits of the laissez-faire model (Fuller 2010) and the changing policies and practices in posthandover Hong Kong. Examining the innovation strategy of the Innovation and Technology Commission (ITC) introduced by the Hong Kong SAR government in 2004, Naubahar Sharif contends that ITC's new strategy "represents a significant departure from the Government's traditional laissez-faire operating principle of 'positive nonintervention"” (2010: 418). A paradigm shift in public administration is also identified by Wong, who suggested that "reducing risk and uncertainty to incentivize otherwise risk-averse firms to enter into the biotechnology sector is considered excessive government intervention. However, things have begun to change, albeit slowly" (2010: 235). Wong cited the construction of the Hong Kong Science and Technology Park (HKSTP) in 2001 and its biotechnology initiative introduced in 2004 as supporting evidence. Phase 3 of HKSTP was completed in 2014, with biotech companies serving as one of the major focused clusters (HKSTP 2014, accessed in 2016). Wong interpreted the construction of HKSTP as an institutional effort to broaden Hong Kong's R\&D base in the life sciences. Although skepticism lingers around Hong Kong's technological capacity to fuel biotech development, Wong suggested that "more recent developments during the 2000s laid the foundation for considerably more lofty ambitions over the longer term, which is to turn Hong Kong into a biotech innovator" (2010: 233).

The prima facie impression of Hong Kong as a merchant's paradise bereft of any serious public commitment to the advancement of science and technology is slowly giving way to the newly constructed image of Hong Kong as a regional biotech 
innovator. Change is afoot in the organization of Hong Kong's R\&D structure and innovation system that counteracts the prevailing "noninterventionist" conventional wisdom. Recent developments in Hong Kong reveal a nascent process of strategic state involvement in driving biotech development. For example, between 2004 and 2006, the term biotech was used in an ambiguous and all-encompassing manner by the ITC. ${ }^{4}$ However, things began to change after 2010, when the Hong Kong government unveiled its developmental plan, which featured an increased public funding for R\&D, of which a significant portion is directed to the biotech sector. It is fair to describe Hong Kong, with its combined quantitative improvement in funding and qualitative paradigm shift in science policy, as a latecomer to the biotech arena or, to borrow Wong's description, "a late entrant into the life sciences sector" (2010: 223).

Perhaps partly because "Hong Kong is a laggard in technological innovation" (Wong 2010: 223), skepticism abounds with regard to the city-state's governing capability or material sufficiency to sustain biotech, which is a cash-burning, high-risk enterprise. Social critics tend to hail Singapore's success in this area to satirize Hong Kong's underachievement: "Even Singapore has shot ahead with its fledging life sciences, medical equipment and biotech industries.... Hong Kong may fantasize about going hi-tech. But it is doing a pitiful job compared with our competing cities" (Lo 2015). Considering the persistent pessimism surrounding Hong Kong's biotech development, I evaluate Hong Kong's recent foray against the backdrop of the previous biotech endeavor in the colonial period. Essentially, I emphasize the differences between the postcolonial biotech momentum with the previous biotech initiative of the $1990 \mathrm{~s}$ in order to assess the degree of gravitas of the latest wave of postcolonial biotech movement.

\section{Leveraging Biotech in Hong Kong: Then and Now}

Hong Kong government's first official biotech policy making dates back to 1988, when the HKIB was established near the Chinese University of Hong Kong, while the BRI was founded at the Hong Kong University of Science and Technology (HKUST). In documenting HKIB's early history and policies to promote downstream processing and incubation services for biotech firms, Baark (2005) identifies a number of reasons behind the doom and gloom of HKIB. Baark assigns market, systemic, and learning failures as the underlying causes for the industrial failure of HKIB's biotech policies. First, HKIB did a lousy job in attracting private capital to invest in valueadded biotech operations and failed to create a private biotech market. Second, HKIB did not do enough to help the local pharmaceutical industry commercialize new biotechnological knowledge, constituting what Baark called a "systemic failure." Third,

\footnotetext{
4 The ITC defines "biotechnology-related companies" as comprising "mainly healthcare-related companies with business in pharmaceuticals, medicinal or healthcare products of traditional Chinese medicine origin, and medical devices and diagnostics." According to Wong 2011, several East Asian states purposely adopt a rather expansive definition of biotechnology, such as the one espoused by the ITC, to include products and services that are not normally considered biotech to bolster a more optimistic prognosis of the biotech industry.
} 
Baark deplores the lack of reflection from the Hong Kong government to learn from these policy mistakes.

Another fiasco was the university-based BRI, under the administration of HKUST. Together with the Biotechnology Committee, a science advisory committee set up in 1992, BRI was intended to liaise academic research with policy makers and bioventure capitalists. Commenting on BRI's subpar performance, Nancy Ip, BRI's director and chair professor at HKUST's Division of Life Science, lamented the shortage of private investment in cutting-edge biotech research. BRI's business development manager further ascribed the absence of biotech market to an industrial inertia: "There's no industry to pick up technology and run with it" (Nature 2001: 4). As for the discretionary power of the Biotechnology Committee, it was suggested that the committee exercised no independent control over its financial resources and held no governing authority (Yuan and Hsu 1995).

The biotech endeavors mediated by the HKIB and the BRI are representative of the first wave of Hong Kong's biotech initiative. This phase of biotech development in Hong Kong was characterized by a noncommittal colonial government, apathetic venture capitalists, and a dormant research community. As Baark notes, "The research and innovation culture and atmosphere in the late 1980s and early 1990s was very weak" (2005: 17). Indeed, investors were reluctant to bet their money on Hong Kong's biotech in the 1990s partly because they did not foresee the emergence of upstream biotech R\&D meeting the needs of downstream biotech demands. The innovation culture of Hong Kong was weak, and the Hong Kong general public was either uninformed of or uninterested in biotech products or services. Therefore, a locally demand-driven biotech market was not anticipated to emerge in colonial Hong Kong.

Compared with the sluggish biotech development in the 1990s, the postcolonial biotech movement was characterized not only by a much larger scale of government sponsorship but also, more importantly, by the high-profile capital investment and research endeavor of entrepreneurial biologists. These scientist-entrepreneurs of biotechnology were the key architects of "Hong Kong's bioscience dream" (Capital 2002) by feeding public expectations toward the therapeutic promises of genetically engineered drugs of local significance and thus creating a niche market that would pay for these Hong Kong-developed drugs that target regional customers. The next section deconstructs the recent discourse surrounding the anticancer recombinant drug known as BCT-100.

\section{The Making of BCT-100: The Rise to Stardom of a Recombinant Drug}

In his fascinating study of the history of the biotech enterprise in the United States, Nicolas Rasmussen put the role of academic biologists-turned-entrepreneurs at the center of his analysis. As Rasmussen wrote, "The biotech enterprise was one produced largely by biologists" (2014: 3), even though these biologist-entrepreneurs were working closely with actors from funding agencies, research institutes, and law firms. Moreover, Rasmussen suggested that the role of academic biologists was particularly prominent in developing new drugs because "pharmaceuticals were always the economic driver of the biotech sector" (1). His excellent biography of five of the first-generation recombinant DNA drugs-human insulin, human growth hormone, 
alpha interferon, erythropoietin, and tissue plasminogen activator-provides a good rationale for my drug-oriented analysis in this section.

In and out of the United States, commercial drug development through genetic engineering has been the most common and the easiest way for academic biologists to reap profits from the new techniques of molecular cloning. Recombinant DNA techniques, in particular, allow business-minded geneticists (nicknamed "gene jockeys," as the title of Rasmussen's book indicates) to tap into the medical marketplace. While Rasmussen used the drug development stories to assess the influence of commerce on the aims, methods, and contents of molecular biology, other scholars have studied the evolving relationship between university life scientists and the business world (Pisano 2006), issues of patentability of biotech products (Ducor 1998), the ethics of pharmaceutical clinical trials (Fisher 2009), and philosophical interpretations of engineered embryos (Maienschein 2014). These scholarly works offer the methodological grounds to study the politics of the new drug and its ramifications on biotech development.

Recent breakthroughs in Hong Kong's biopharmaceutical research are at the heart of the latest biotech momentum. The discovery of the anticancer drug BCT-100, led by a clinical oncologist and two academic biologists, is central not only to the biotech bandwagon but also to the identity of the Hong Kong biomedical research community. The drug was lauded as the first "homegrown" drug to ever receive investigational new drug (IND) approval from the US Food and Drug Administration (FDA) to proceed with clinical trials. ${ }^{5}$ In recognition of the unprecedented clinical breakthrough, a gold medal with the jury's commendation was awarded to the three Hong Kong scientists at the Thirty-Third International Exhibition of Inventions, New Techniques, and Products at Geneva. Even more striking, the birth of the drug was celebrated as "the pride of Hong Kong people" (Capital Weekly 2013), and the therapeutic value of arginine depletion (the mechanism on which BCT-100 is based) is heralded as the solution for other types of "Cantonese cancer" (UGC 2007b). The FDA recognition, the Geneva honor, and the ethnic connotation are the three means by which Hong Kong biologistentrepreneurs groomed the new recombinant drug for stardom.

The story of BCT-100 as told through the media lens is a hero's tale. At the center of the narrative are the three scientists responsible for researching the new recombinant drug: Paul Ning-Man Cheng, ${ }^{6}$ Thomas Yun-Chung Leung, and Thomas Wai-Hung Lo. Cheng owns a private clinic in Central, Hong Kong; Leung and Lo are academic biologists based at the Department of Applied Biology and Chemical Technology at the Hong Kong Polytechnic University (PolyU). According to Leung and Lo, Cheng was the first one who came up with the research idea. During Cheng's professional interaction with a patient diagnosed with advanced hepatocellular carcinoma (HCC) in 2001 , he noticed that the patient's periodic health improvement probably had

\footnotetext{
5 Investigational new drug (IND) applications exempt drugs from many FDA regulations so that they can be transported or distributed across state lines. The US Code of Federal Regulations (21 CFR part 312) addresses the procedures and requirements for filing an IND application ("Code of Federal RegulationsTitle 21-Food and Drugs," www.fda.gov/MedicalDevices/DeviceRegulationandGuidance/Databases /ucm135680.htm, accessed 10 March 2016).

6 Paul Cheng is well known in Hong Kong for treating cancers and tumor-related illness for local celebrities, such as Anita Mui, who passed away in 2003, and more recently the lawyer-socialite Kai-Pong Chau. A local tabloid magazine lauded Dr. Cheng as a “divine hand for treating cancer” (治癌聖手; Eastweek 2009).
} 
something to do with his very low blood level of arginine. Cheng then teamed up with PolyU-based Leung and Lo to further study the causal relationship between lowering of blood arginine concentrations and inhibiting cellular proliferation of HCC (UGC 2007a). It took the three scientists nearly six years to produce a significant research paper on this topic. Their first peer-reviewed article was published in 2007 in the highimpact journal Cancer Research, published by the American Association for Cancer Research (Cheng et al. 2007). With this essential publication in hand, they applied for FDA clearance to conduct clinical trials in 2008 (NIH 2009). Phases I and IIa of BCT-100 were completed in 2012, with additional stages of phase II still under way.

Jill Fisher (2009) has remarked on the duration and developmental phases of clinical trials. As Fisher details, the clinical development cycle of INDs proceeds in three primary phases and one secondary phase. After a preclinical toxicity test on animal subjects, the IND will go through a phase I safety test, which usually enrolls about 28-80 healthy human subjects to go through twenty-one trials, which takes up to one year to complete. About 70 percent of INDs will proceed to phase II studies, which normally recruit one hundred to three hundred diseased human subjects. An average phase II study will take up to two years and goes through six trials to obtain preliminary information on the efficacy, tolerability, and other safety information of the drug from several hundred of patients with the targeted disease. Only half of the INDs will pass this stage and enter phase III, which is the most commonly known phase in popular understandings of clinical trials. This phase requires one thousand to three thousand volunteers diagnosed with the targeted disease to participate in an average of ten trials to compare the drug's efficacy against standard treatment or placebo effect over two to four years. The end of phase III marks the completion of the primary phases of clinical development cycle, after which the FDA will determine whether a new drug application (NDA) will be issued. A secondary phase, phase IV, known as "postmarketing" research, is in place after the drug appears on pharmacy shelves. Phase IV usually takes 2-10 years, with the input of several thousand diseased human subjects. The purpose of phase IV trial is to measure the cost-benefits and short- and long-term efficacy of the drug. Only 25-30 percent of INDs will survive the entire clinical development cycle and become established medical treatments (Fisher 2009).

Because the clinical trials of BCT-100 are still ongoing, ${ }^{7}$ it is difficult to tell when or whether it will get to the next step - filing an NDA. ${ }^{8}$ Cheng, the leading oncologist on the team, certainly realized the risks and challenges ahead. In a Chinese-language magazine article intended for local audiences, Cheng relates the hardship that he and his team had endured throughout the R\&D stage of BCT-100. Cheng and the company's cofounder Jun Sing Lee told the reporter, “[We] wouldn't have embarked on this process had we known how difficult it was going to be." They emphasize that it was all the more arduous for their team because "the United States has no confidence in Hong Kong's biopharmaceutical research” (Capital Weekly 2013). The total time

\footnotetext{
7 Phase III trials of BCT-100 are still recruiting participants at the time of writing; see clinicaltrials.gov/ct2 $/$ results?term $=$ BCT-100\&Search $=$ Search $($ accessed 7 March 2016).

8 The NDA (new drug application) is defined as "the vehicle through which drug sponsors formally propose that the FDA approve a new pharmaceutical for sale and marketing in the U.S." (www.fda.gov /Drugs/DevelopmentApprovalProcess/HowDrugsareDevelopedandApproved/ApprovalApplications/New DrugApplicationNDA/, accessed 10 March 2016).
} 
spent on conducting laboratory experiments for the Hong Kong R\&D team, in Cheng's estimation, was three to five times more than their Euro-American counterparts in order to gain the coveted IND clearance. Despite these difficulties, Cheng says, "When our achievement is recognized by the US biopharmaceutical authority, I feel that all the wait and tribulation are worthwhile" (Capital Weekly 2013). The weight of the FDA recognition of BCT-100 should not be underestimated. As Cheng explains its significance on the company's home page, "It is challenging to conduct bio-technological research in Hong Kong. The issuance of US FDA's IND to conduct clinical studies in the US is a stamp of approval that our technology is on a par with the rest of the developed world" (BCT Company News 2012). Echoing Cheng's characterization, Lee said that the primary motivation behind the making of BCT-100 is to improve the overall biopharmaceutical R\&D capacity of Hong Kong, with profitability only a secondary concern (Capital Weekly 2013). These biologist-entrepreneurs' public-good-seeking impetus is further highlighted by local media. Sing Tao Daily (2012), Hong Kong's second largest Chinese-language newspaper, communicated the importance of the US accreditation of BCT-100 by describing the drug as "Hong Kong manufactured" (港產), rather than using the generic label "China-manufactured" (國產). In the body text, the drug was upheld as "Hong Kong's first independently researched and developed new drug for curing advanced liver cancer” (香港首隻自主 研發的晚期肝癌新藥, my emphasis).

While it is an overanalysis to make too much out of one media portrayal, it seems appropriate to view the media discourse surrounding BCT-100 through the prism of what Sheila Jasanoff called the "alliance between biology and power." In contemplating the relationship between biotechnology and imperialism, Jasanoff put forth the idea that biotech and life science technologies in general have served as instruments for exercising biopower of the governing elites since the imperial age: "The life sciences, as much research has shown, have long been implicated in serving the designs of empire builders. Modern biotechnology, I suggest, can similarly be drawn into the service of possible imperial constructions, and I ask in what ways this particular global production system is likely to influence today's transboundary exercises of political, economic, and cultural power" (2006: 276). Jasanoff is of the view that biotech is a means that the corporatized neoliberal state used to justify and maintain its governing legitimacy. From this perspective, the discovery of the new drug captures the attention of the Hong Kong media because it resonates with the populist imagination of the local community: it relates to "the biopolitical imagination of the neoliberal state and its corporate partners, whose innovative capacity is as essential to underwriting state action as is the capacity of expert professionals to define and apply the technical criteria of governmentality" (283). While the media depiction of BCT-100 highlights the newcomer status of Hong Kong in the global biotech sector, it is not separate from the global politics of biotech.

The recent biotech boom in Hong Kong offers a case in point to analyze the past and present connection between biological knowledge and power consideration. A sketch of the sociopolitical history of Hong Kong is perhaps apropos: Hong Kong is not a nation-state, an independent country, or a legitimate member in the United Nations. Its complicated history as a former British colony and the first example of China's implementation of "one country, two systems" (a notion invented by Deng Xiaoping to integrate Taiwan, eventually, into China's sovereignty) sets it apart from the rest of 
Asian Tigers. ${ }^{9}$ From a crown colony in the British Empire to a special administrative region under the People's Republic of China, Hong Kong also transformed from being "the world's greatest experiment in laissez-faire capitalism," as Milton Friedman dubbed it (Economist 2010), to the first series of experiments in implementing capitalist systems in a titular communist country. In examining the history of the Bacteriological Institute of Hong Kong, Theresa MacPhail wrote that it "is particular only to Hong Kong, imbued with the city's colonial past as an important trade hub and center of British colonial rule" (2014: 86-87). MacPhail further suggested that it is felicitous to view Hong Kong's infectious disease research and public health policy making via "the dual lenses of its postcoloniality and its "Chineseness"' (78) because the city-state has never been able to completely shake off either the haunt of the colonial past or the apprehension of China's future. I concur with MacPhail's characterization of Hong Kong, and would like to add that this type of postcolonial negotiation is by no means limited to the city's epidemiological research; rather, the city's latest biotech discourse on BCT-100 cannot be understood without this conceptualization.

With this context in mind, it is perhaps understandable why entrepreneurial biologists such as Cheng are eager to highlight Hong Kong's biopharmaceutical R\&D capacity (which was absent in colonial Hong Kong), while the journalists at Sing Tao Daily emphasized the locality of the genesis of BCT-100. Both scientific and media actors were probing into the identity crisis of the Hong Kong people. Trapped in the mode of what MacPhail called "postcolonial temporality," the average Hong Kong psyche is afflicted with an enduring identity crisis, which again is unique among fellow East Asians: South Koreans are fanned by a fervent nationalistic sentiment toward Hwang Woo-suk's stem cell research (Thompson 2010); Taiwanese are highly conscious of the military-political ramifications of sitting in the shadow of a rising China (Liu 2012); Singaporeans celebrate their half century of independent statehood while being acutely aware of their resource shortage as a tiny state (Gelfert 2013). Even though both Hong Kong and Singapore fall under the "technoglobalist" innovation category (Keller and Samuels 2003), this technoglobalist impulse is differently articulated in Hong Kong. Specific to Hong Kong is the opportunity and challenge offered by its geopolitical proximity to China. Pro-China business leaders tend to emphasize the lucrative opportunity that closeness provides: "We really are at the doorstep of the huge Chinese market. That is something that other competitors cannot challenge. They can't move their countries closer to China!" (Sanders 2012: 1646). But proximity can also breed contempt. The perennial identity crisis of Hong Kong people is symptomatic of the psychosocial burden of living in China's immediate vicinity, which sets Hong Kong apart from other East Asian sites of inquiry.

While the Sing Tao Daily reporters displayed pride in the FDA approval of BCT100 , previous awards set a powerful stage for the scientist's claim of the medical benefits of the homegrown drug. Prior to the FDA recognition, the gold medal awarded by the Geneva international convention was another important way to affirm the collective identity of Hong Kong's biomedical researchers, for whom a stamp of

\footnotetext{
9 Taiwan shares a substantial Japanese colonial history with South Korea. Singapore was once a British crown colony, but it declared independence in 1965, whereas Hong Kong never achieved political independence.
} 
approval from the international community is highly valued. The popular tabloid newspaper Apple Daily (2005) report of the drug's gold medal highlights the endeavors spearheaded by academic scientists Leung and Lo at PolyU. The title of the report, "PolyU Succeeds in the R\&D of an Anti-Liver Cancer Drug," puts the local university, rather than the biologist-entrepreneurs, in the spotlight. Subsequent to the Apple Daily coverage, the Research Grants Council featured the discovery of BCT-100 in its biannual newsletter, Research Frontiers, under the aegis of the University Grants Committee (UGC). ${ }^{10}$ Titled "New Cancer Drug Breakthrough for Hong Kong," the article put the exclusive focus on Leung and Lo, with a picture of the two academic scientists in the main text and their contact information at the end of the article (UGC 2007a). Cheng was not particularly featured in this UGC-sponsored article probably because he was a private practitioner rather than an academic scientist working in an UGC-funded institution. The central figure in the article is Leung, who summarized the significance of BCT-100 this way: "The breakthrough also won us a Gold, as well as a Special Gold Award from the Ministry of Education and Research of Romania, at the 33rd International Exhibition of Inventions, New Techniques and Products at Geneva and has generated strong interest from around the world. Most important, however, is the ray of hope it will bring to liver cancer patients and possibly to other cancer patients as well" (UGC 2007a). The Geneva accolade was regarded as unprecedented glory to the Hong Kong biomedical research community before the advent of the FDA approval. The Beijing-backed newspaper Global Times (2005) also reports on the Geneva prize with an article focusing on the international honor. Unlike the Hong Kong-focused discourses in Sing Tao Daily and Capital Weekly, the Global Times's depiction of the drug as "Hong Kong's New Drug" is ambiguous because it does not differentiate the difference between Hong Kong-manufactured and Chinamanufactured products, nor does it highlight the specificity of Hong Kong's R\&D capacity. In the text, BCT-100 is described as "the first drug researched and developed in Hong Kong to go through clinical trials" (首項在香港研發並可進行臨床試驗的 藥物). This description indicates that Hong Kong was merely a locale, the birthplace of BCT-100, but it is not clear whether Hong Kong researchers or mainland Chinese students studying in Hong Kong universities were responsible for the BCT-100 R\&D activities. ${ }^{11}$ Given a lack of distinction between Hong Kong and China and a lack of attribution to Hong Kong-specific cultural rhetoric, it seems that the way the Global Times foregrounds the international recognition of the drug reflects the strategic interests of this People's Daily-sponsored newspaper.

The final recipe to cultivate public enthusiasm toward the medical benefits of BCT100 is the invocation of "Cantonese cancer." In the same issue of Research Frontiers that publicized the discovery of BCT-100, an article by the title of "Gene Mapping

\footnotetext{
10 The UGC was established in Hong Kong in 1965 to administer public funding to higher education institutions. A few years later, the government set up a Research Grants Council under the umbrella of the UGC to advise and monitor the use of public research grants in these academic institutions. UGC and RGC are the primary funding vehicles for the higher education sector in Hong Kong, where nearly all of the higher education institutions are publicly funded. For more information, see www.ugc.edu.hk/eng/rgc /index.htm (accessed 10 March 2016).

11 Most laboratory-based postgraduate science students in Hong Kong come from mainland China, which causes distress among the disgruntled younger generation who blame their Chinese compatriots for "stealing" education opportunities from them.
} 
Fights 'Cantonese' Cancer" discussed the research outcomes of molecular geneticist Lo Kwok-Wai from the Chinese University of Hong Kong. Wai's research agenda focused on the genome mapping of pharmacological oncogenes for nasopharyngeal carcinoma (NPC), a type of head and neck cancer. The article commenced with a brief introduction of NPC as a Cantonese-prone cancer: "NPC, a relatively rare type of head and neck cancer, is also known as the 'Cantonese' cancer in view of its high prevalence among the Southern Chinese and those of Cantonese origin. Around 80 percent of the illness occurs in southern China and among Chinese in the Southeast Asian region" (UGC 2007b). Although the discursive image of "Cantonese cancer" was specifically applied to NPC rather than all types of cancers, the rest of the article established the linkage between gene mapping and cancer therapy in general. The government's funding agency took interest in the genetic mapping of NPC cells due to its potential to enable "the development of anti-cancer drugs and new methods of treatment" (UGC 2007b). In the same issue of Research Frontiers, Leung remarked on "the ray of hope [BCT-100] will bring to liver cancer patients and possibly to other cancer patients as well" (UGC 2007a). The commonality between genetic therapy based on NPC genome mapping and arginine deprivation therapy derived from BCT-100 is that they both demonstrate a regional (i.e., Cantonese-speaking region) need and demand for new forms of cancer treatment. This is evident in the joint attempts to generalize a specific type of research on a specific type of cancer to other forms of cancer treatments. On the one hand, Wai gave the prognosis of the oncogenetic study of NPC: "Looking forward, more work is being done in the effective use of these gene therapies to explore the anti-tumor effects of various pharmacological agents" (UGC 2007b). On the other hand, Leung and Lo have since broadened the arginine depletion research agenda from HCC (liver cancer cells) to melanoma (Lam et al. 2010) and prostate cancer (Hsueh et al. 2012), whereas Cheng was involved in the study of the antileukemia effects of BCT-100 (Mussai et al. 2015). In other words, the label "Cantonese cancer" is specific to NPC, but the therapeutic value of oncogenetic treatment is not.

In her seminal study of the meteoric rise of proto-oncogene theory in cancer research, Joan Fujimura suggests "different actors used proto-oncogene research to maintain and extend their lines of work and simultaneously extended the reach of proto-oncogene research and molecular genetic technologies" (1996: 152). Although this paper does not examine the history of oncogene research, Fujimura's insight is instructive because what her study underlines is the social construction of cancer knowledge by scientists and nonscientists. As she argues, "The enthusiasm for a particular research problem, and for a particular technical approach, is a social phenomenon" (3). Not only is cancer research a social phenomenon, but cancer's alarming health threat to the developing world has become a global issue. Margaret Chan, director general of the World Health Organization and former director of health in Hong Kong, recently commented on the global health crisis posed by noncommunicable disease: "The worldwide increase of non-communicable diseases is a slowmotion disaster... but the unhealthy lifestyles that fuel these diseases are spreading with a stunning speed and sweep" (Chan 2011).

As China becomes the world's second largest economy, a staggering number of its people are now suffering from preventable, noncommunicable diseases, of which cancer is a leading cause of death (American Cancer Society 2016). Therefore, the economy of cancer therapy constitutes a seller's market for oncological treatment, and 
this also explains why cancer commands the highest level of scientific enthusiasm in biotech and pharmaceutical companies, followed by diabetes and rheumatoid arthritis. Indeed, the scientific enthusiasm that surrounds BCT-100 was jointly produced by molecular geneticists, representatives from academic funding agencies public health officials, and stakeholders from biotech firms. Despite the growing skepticism among the scientific community regarding the equivalence of NPC and "Cantonese cancer," 12 academic biologists and funding agencies in Hong Kong show no sign of deterrence from drawing this connection. The relevance of the cultural image of Cantonese cancer to the perception of BCT-100 illustrates the interplay between the medical promise of molecular genetic cancer research and the business enthusiasm of the drug-centric biotech enterprise.

In many ways, BCT-100 is a paradigm-shaping drug that is on its way to becoming the first homegrown "blockbuster" drug in Hong Kong. Bombarded with many rosy portrayals and some overinflated promises, one is prompted to ask how different BCT-100 really is from other previous Hong Kong-developed drugs. The next section compares and contrasts the case of BCT-100 with the antimalaria vaccine TBV25H, followed by investigations of other contemporary biotech developments, to highlight the discontinuity of the postcolonial biotech dynamics.

\section{From TBV25H to Focusing on Biomedical Problems of Regional Significance}

Although Leung narrated BCT-100 as "the first drug to be developed in Hong Kong to proceed to clinical trials" (UGC 2007b), other scholars had offered pre-BCT-100 events to contend with this notion of unprecedented biomedical innovativeness. In analyzing Hong Kong's "failed" biotech initiative in the 1990s, Baark described the clinical trial of TBV25H, an HKIB-sponsored vaccine, as "the first human safety trial of a therapeutic drug developed in Hong Kong" (Baark 2005: 19). As an antimalaria vaccine built upon the mechanism of blocking the transmission of malaria parasites, the R\&D of TBV25H was undertaken by David Kaslow and Joseph Shiloach from the Molecular Vaccine Section of the Laboratory of Malaria Research at the National Institute of Allergy and Infectious Diseases (NIAID) at the US National Institutes of Health (NIH). After the preclinical research findings were published in 1994 (Kaslow and Shiloach 1994), HKIB applied for an R\&D partnership grant from the United Nations Development Program, World Bank, and World Health Organization Special Program for Training in Tropical Disease Research. According to Albert Chang, then HKIB chairman, the purpose of the R\&D partnership grant was "to train research personnel in HKIB's Good Manufacturing Practice-Manufacturing Technology Center...to scale up the production" of TBV25H (1999: 2). In other words, TBV25H was first researched in the United States, and only after the upstream research was completed was HKIB interested in the mid- to downstream production of the vaccine for the purpose of staff training. The R\&D partnership grant enabled HKIB to collaborate with the NIAID to file an IND application to conduct the clinical

12 A recent article published in the Chinese Journal of Cancer questioned the appropriateness for calling nasopharyngeal carcinoma "Cantonese cancer" in view of new genetic and historical analyses (Wee et al. 2010). 
trials of TBV25H in Hong Kong and the United States simultaneously. The role of HKIB is mainly to "manufacture the bulk clinical trial materials for the Phase I human studies" (Chang 1999: 2).

Compared with the glory of BCT-100, the clinical development of TBV25H was lackluster and not very indigenous to Hong Kong. Although both TBV25H and BCT100 involved some degrees of input from Hong Kong in filing and conducting the FDA clinical trials, TBV25H was not primarily a Hong Kong-driven biomedical innovation. The high-end research phase of TBV25H was conducted elsewhere, with no participation from Hong Kong scientists. The contribution of Hong Kong in the clinical development of TBV25H is marginal in the sense that Hong Kong was mainly involved in the low-end manufacturing phase of clinical trial materials. Moreover, although both the NIH and HKIB were behind the IND application, the partnership grant through the special training program allocated to HKIB was used to finance the application. Couched in the name of international collaboration, the uneven resource distribution reflects the asymmetrical power dynamics behind the NIH-HKIB partnership. In the clinical development of TBV25H, HKIB was left in a dependent position by following the lead of the NIH.

That the clinical development of TBV25H was mainly driven by the NIH rather than HKIB provides a strong but incomplete explanation for its frigid reception from the Hong Kong mainstream society. Unlike the expressed media interests over BCT100 , TBV25H received no popular portrayal from any local media. The only media avenue that mentions the clinical achievement of TBV25H is HKIB's own website. ${ }^{13}$ The paucity of media interest in TBV25H likely has to do with the perceived irrelevancy of the antimalaria vaccine due to the changing medical needs of the Hong Kong society. While malaria was once infamously regarded as "Hong Kong fever" among the British sailors in the 1890s, it had ceased to plague the postwar Hong Kong population by the 1970s thanks to the antimalaria efforts of the colonial government (Yip 2009). In writing about the history of malaria control and sanitation programs in modern East Asia, Ka-che Yip (2009) explicated the Eurocentric image of tropical disease as part of the "uncivilized" and backward culture of the overseas colonies. As Yip argued, "The British in Hong Kong also understood many of the diseases that they encountered, including malaria, to be products of the uncivilized and unwholesome lifestyle of the local population and the untamed environment they lived in. Their civilizing mission was certainly reinforced by their sense of superior Christian morality" (2009: 5). This quote displays the explicit connection between imperialist ideology, notion of religious superiority, and efforts of disease control and prevention in early colonial Hong Kong.

The history of antimalaria policy in Hong Kong reveals a specific mode of colonial malariology that was firmly entrenched in British imperialism. However, with the eradication of malaria in the late twentieth century, the fin de siècle idea of "tropical" medicine was becoming more distant and immaterial in the mind-set of average Hong Kong citizens. Malaria was no longer a major health threat by the 1970s, at the same time as Hong Kong was transformed into a newly industrialized economy. In 1970 the

13 See Hong Kong Institute of Biotechnology, www.hkib.org.hk/gb/services/biologics.htm (accessed 10 March 2016). 
five leading causes of death in Hong Kong were, in descending order of mortality rate, cancer, heart and hypertensive diseases, pneumonia, cerebrovascular lesions, and tuberculosis (Yip 2009). The Hong Kong Department of Health (2007, accessed in 2016) reckoned that in 2006 more than 61 percent of the total mortality rate in Hong Kong was attributable to preventable noncommunicable diseases, of which cancer accounted for over 32 percent of registered deaths. Cancer also ranked first and killed two-fifths of the population prematurely, as measured by the number of potential years of life lost at seventy-five years of age. With the economic development and health enhancement, "tropical" diseases such as malaria ceased to afflict the Hong Kong populace, for whom noncommunicable diseases such as cancer presented a much more immediate health concern. While I do not deny the effect of the legacy of epidemic control on present public health policy making, ${ }^{14}$ I do want to highlight the perceived irrelevancy of malaria research to the general needs of the Hong Kong people in the twenty-first century. The perceived urgency of biotech research to the local medical needs is an important factor separating TBV25H from BCT-100. While $\mathrm{TBV} 25 \mathrm{H}$ is seen as serving (chiefly) the affected population in developing tropical countries, BCT-100 is not. The anticancer drug is much more marketable to the Hong Kong population than is the antimalaria vaccine. Table 1 summarizes the major points of differences between TBV25H and BCT-100.

Through the above comparative analysis, I hope to put into perspective the postcolonial biotech development empowered by Hong Kong biologist-entrepreneurs. Unlike the previous wave of biotech initiative, as typified by TBV25H, the postcolonial biotech enterprise was shaped by a much more salient and vigorous participation of business-savvy molecular biologists, and their efforts are not limited to the research and promotion of BCT-100. In what follows, I examine other entrepreneurial attempts of academic biologists with the emphasis placed on the business-oriented motive that underlines the postcolonial biotech development in Hong Kong.

The media-concerted campaign of BCT-100 transforms the three Hong Kong scientists into pioneering inventors and life-saving scientists rather than profit-seeking entrepreneurs. Yet the very name of the drug, BCT-100, is a reminder of the corporatedriven nature of biopharmaceutical research. What lies behind the development of the first homegrown drug is not just the biotech company by the name of Bio-Cancer Treatment Ltd. but, more important, the growing realization among the academic biologists that they need to focus on biomedical research topics of regional significance if they want to turn novel biomedical technology into commercially viable products.

In posthandover Hong Kong, academic biologists were among the first groups of actors to recognize the need to pursue biomedical research topics of regional relevance in order to catalyze the local biotech development. Michael Yang, department head of biomedical sciences and chair professor of chemistry and biomedical sciences at the City University of Hong Kong, spoke of the significance of "focusing on biomedical problems of regional importance" in order to "find a niche in the crowded" marketplace of biotech innovation (Nature 2001: 4). Yang cofounded Multigene Diagnostics,

\footnotetext{
${ }_{14}$ MacPhail (2014) recently examined the linkage between the epidemic past of colonial Hong Kong and the post-2003 global efforts against new types of communicable diseases triggered by the outbreak of SARS (severe acute respiratory syndrome).
} 
Table 1 Major characteristics of TBV25H versus BCT-100

\begin{tabular}{|c|c|c|}
\hline Characteristic & TBV25H & ВСТ-100 \\
\hline Full name & $\begin{array}{l}\text { Transmission-blocking vaccine } \\
\text { with Pfs } 25 \text { and histidine tag }\end{array}$ & $\begin{array}{l}\text { Bio-cancer treatment- } 100 \\
\text { (pegylated human recombinant } \\
\text { arginase) }\end{array}$ \\
\hline Period of discovery & Colonial Hong Kong & Postcolonial Hong King \\
\hline Use & Malaria immunization & Cancer therapy \\
\hline Target audience & $\begin{array}{l}\text { Affected population in } \\
\text { tropical countries }\end{array}$ & $\begin{array}{l}\text { Primarily Hong Kong cancerous } \\
\text { population }\end{array}$ \\
\hline R\&D site & $\begin{array}{l}\text { National Institutes of Allergy and } \\
\text { Infectious Diseases at the } \\
\text { National Institutes of Health, } \\
\text { United States }\end{array}$ & $\begin{array}{l}\text { Hong Kong Polytechnic } \\
\text { University, BCT } \\
\text { International Ltd., Hong Kong }\end{array}$ \\
\hline Principal investigators & David Kaslow, Joseph Shiloach & $\begin{array}{l}\text { Paul Cheng, Thomas Leung, } \\
\text { Thomas Lo }\end{array}$ \\
\hline Clinical collaborators & $\begin{array}{l}\text { Prince of Wales Hospital, Chinese } \\
\text { University of Hong Kong, } \\
\text { US National Institutes of Health }\end{array}$ & $\begin{array}{l}\text { Queen Mary Hospital, } \\
\text { University of Hong Kong } \\
\text { Chinese University of Hong Kong }\end{array}$ \\
\hline Sponsors & $\begin{array}{l}\text { United Nations Development Program, } \\
\text { World Bank, and World Health } \\
\text { Organization Special Program for } \\
\text { Research and Training in Tropical } \\
\text { Diseases }\end{array}$ & $\begin{array}{l}\text { BCT International Ltd., } \\
\text { Hong Kong Science and } \\
\text { Technology Park, Hong Kong } \\
\text { Polytechnic University }\end{array}$ \\
\hline Portrayal & $\begin{array}{l}\text { "First human safety trial of a } \\
\text { therapeutic drug developed } \\
\text { in Hong Kong" }\end{array}$ & $\begin{array}{l}\text { "The pride of Hong Kong people" } \\
\text { "Hong Kong's first independently } \\
\text { researched and developed new } \\
\text { drug for curing advanced } \\
\text { liver cancer" }\end{array}$ \\
\hline
\end{tabular}

Ltd., a City University spinoff biotech firm specializing in molecular diagnostics. As the first biotech company admitted to the Incu-Bio Business Incubation Program at HKSTP in 2009, Multigene had the ambitious goal to harness the rapidly growing Chinese market (South China Morning Post 2010). As the executive director of Multigene told the media, "We have a number of products that are in great demand in China, such as the human papillomavirus (HPV) detection and genotyping kits for cervical cancer screening" (Sanders 2012: 1643). HPV is a type of sexually transmitted disease (STD) that accounts for 70 percent of cervical cancers worldwide. According to a CNN news report, STD-related diseases are on the rise in China, which generates debates over the need to promote sex education in China (Steinfeld 2014). The HPV vaccine is currently only available in Hong Kong, but Chinese scientists are now urging the Chinese government to subsidize a semimandatory HPV vaccination program for the high-risk community (Zhang et al. 2013). As STDs become a bigger 
threat to China's public health, they represent a more lucrative market for Multigene and other Hong Kong biotech firms making similar products. Multigene's strategy to prioritize STD diagnostic services exemplifies Yang's philosophy of "focusing on biomedical problems of regional importance."

The success of Multigene attracts more companies to follow its business model. Vitargent Biotechnology Ltd. is a Hong Kong start-up firm that concentrates on food detection technology. The company recently announced a new testing method for detecting chemical toxins in food and cosmetics by using zebrafish embryos as an active agent. The innovative food-testing technology was intended to capitalize on the food safety problems in China, which became ignominious after reports of babies dying from consuming melamine-contaminated formula in 2008. Besides poisonous milk, recycled cooking oil (otherwise known as "sewer oil"), questionable meats, and fake eggs also triggered alarming concerns over the reliability of China-supplied food products. ${ }^{15}$ The food safety issue might be a matter of public embarrassment if not a legitimacy crisis for the governing elites in Beijing, but it is viewed as a thriving market in the eyes of Vitargent executives. As a South China Morning Post article suggests, Vitargent "sees a huge opportunity in China, where multiple food scandals have rocked consumer confidence, particularly with regard to milk powder and cooking oil" (Griffiths 2015). It is uncertain whether Vitargent will reap profit from its biotesting technology, although a San Francisco-based venture capital group seems to think so, as it has invested somewhere between US\$5 million and US\$15 million in the Hong Kong company (Griffiths 2015; Ma 2015).

Multigene and Vitargent set the trajectory for pro-business Hong Kong biotech firms to capitalize on the booming Chinese market. The magnetic market force of mainland China attracts Hong Kong biologist-entrepreneurs to invest in biotech services that dovetail with the growing demands from the Chinese customers. As Wong acutely captures, "China offers 'low hanging fruit' for would-be bio-entrepreneurs based in Hong Kong” (Wong 2010: 227). HPV vaccine and food testing are just two examples of these "low hanging fruits" offered by the immense Chinese market. Through harvesting these fruits in the flourishing Chinese garden, the Hong Kong biotech firms are actually shaping an emerging regional biotech market. Even though the motive is profit, these Hong Kong biotech firms still play an important part in creating a local biotech marketplace, which has been long awaited by investors and scholars alike. As late as 2004, a book focused on Asia's biotech industry suggested: "The major problems with financing biotech ventures in Hong Kong are that there is only a small local market for biotech products and that the country has a history of expertise in finance and the service industry, not in world-class research and development" (Bergeron and Chan 2004: 257). The recent efforts of Hong Kong biologistentrepreneurs seem dedicated to address the issue explicitly raised by Bergeron and Chan, and a feeble biotech market and a weak R\&D capacity are no longer the main hindrances to Hong Kong's biotech development. The biomedical breakthrough of BCT-100 strengthened Hong Kong's R\&D base, while the pro-China business approach of the Hong Kong biotech firms bolstered a regional biotech market. Although biotech is an inherently risky and speculative enterprise, these recent

15 See Foster 2011 for an inventory of top ten Chinese food scandals since 2008. 
strategies directed by the entrepreneurial life scientists have significantly changed the stereotypical image of Hong Kong as a financial paradise unsuitable for biotech research and market development.

\section{Discussion: Hong Kong and "Communities of Fate"}

In theorizing the relationship between biotech and bioethics in Asian countries, Ong (2010) introduced an analytical framework called "communities of fate" to make sense of new biotech regimes in multiple locations. Grounded in an anthropological approach to bioethics, the concept of communities of fate highlights the interactions among politics, science, and ethics in Asian contexts that are distinct from mainstream Western ethical reasoning. Specifically, three practices are constitutive of such communities of fate. First, the biotech programs in Asia's emerging economies are mostly state driven and fueled by a strong sentiment of postcolonial nationalism. Second, biotech innovations often bring with them hidden symbolic meanings, as imprinted in the genetic predisposition for certain diseases among Asian populations. Third, traditional beliefs about ethnicity and folk religion are carried over to interpret new forms of biomedical knowledge and practices.

The preceding sections in this study of Hong Kong's biotech reveal both convergence and divergence between the empirical data in Hong Kong and the theoretical underpinning of communities of fate. The essential features of "Hong Kong's bioscience dream" correspond nicely to each of the three components in Ong's tripartite theory. Regarding postcolonial nationalism, Ong writes: "As state-led enterprises, biotechnologies are allied to nationalist efforts to overcome past humiliations and to restore national identity and political ambition. The examples mentioned above all register a deep nationalist fervor in the race to be 'number one' in cutting-edge sciences, with its promise of a lucrative science-driven economy" (2010: 3). At first glance, Hong Kong seems to diverge from the modular regime of state and nationalist collectives in biotech governance. Although many biotech enterprises in Hong Kong (e.g., Multigene and Vitargent) are private rather than state owned, the postcolonial biotech boom in the city is heavily backed by the SAR government, as evident in the reportage of SAR government officials in the 2012 Science-sponsored supplement that I discussed in section 1 (Sanders 2012). In addition, the marketing campaign of BCT-100 exhibits a postcolonial desire to enhance local identity and prestige by presenting the drug as, among other things, the first homegrown experimental drug.

Corresponding to the second component in Ong's theory, the symbolic dimensions of Hong Kong's bioscience dream are illustrated in the advertisement strategies of BCT-100. In advertising the medical benefits of BCT-100, the three biologist-entrepreneurs did not just highlight the purely scientific facts of the drug. Rather, Cheng commented on the unusually high level of skepticism held by the FDA regarding the city's R\&D capacity; Leung and Lo cited the Geneva accolades to bolster the unprecedented achievement of the drug, even though TBV25H preceded BCT-100 as the first Hong Kong-manufactured drug to go through human safety clinical trials.

The third aspect of communities of fate relates to the new forms of assemblages between biotech innovation and traditional belief systems. As my analysis shows, the emergence of new forms of biotech knowledge in Hong Kong is constructed with the 
cultural and political tropes of independence, ethnic pride, and regional resources. BCT-100 is "the pride of Hong Kong" because it is the first homegrown drug that focuses on a common noncommunicable disease that also resonates with the "Cantonese" ethnicity, which makes the drug salable to the Cantonese-speaking community in southern China. Making the new recombinant drug was not only a biomedical breakthrough but also a convergence of the life-saving medical promise with the moneymaking commercial interests of biotech enterprise. Similar to other critical studies of biotech in East Asia, Hong Kong's biotech research offered a pivotal point of reference to understand the multiple layers of meanings that are integrated into "Hong Kong's bioscience dream."

In the meantime, the Hong Kong case also offers points of divergence from East Asia's communities of fate. The array of ethnographic studies in Ong and Chen's coedited volume Asian Biotech "explores the political and ethical implications of biotechnologies outside contexts of Western advanced liberalism" (Ong 2010: 43). Yet Hong Kong does not fall under this category of non-Western developmental states that tend to deprioritize liberal democracy. Despite the many quarrels between policy makers, legislative councilors, and the general public in Hong Kong, few called into question the full extent of Western-style capitalism practiced in Hong Kong. Not only does the city-state take pride in its total embrace of the free enterprise system, but it is also willing to tolerate the many social consequences that came with widespread income inequality. While economic fluctuation and social unrest sometimes invite civil disobedience, protestors often assign culpability to China's overlordship of Hong Kong rather than the systematic weaknesses of radical capitalism. It is safe to say that many Hong Kongers openly espouse the British legacy of free trade and liberal democracy, while few question the footprints of Western imperialism and racial discrimination. This political culture is discernible in the biotech sphere, for it is the business-minded biologists rather than state actors or government officials who are responsible for creating the momentum that shapes the postcolonial biotech phenomenon in Hong Kong. Inspired by the need to "focus on biomedical problems of regional importance," academic biologists from university spinoffs skillfully specialized in biotech products that were in great demand in China, such as HPV diagnostic kits and biotesting technology. Realizing the need to find a regional niche market to sustain new technologies, biologist-entrepreneurs were incentivized to connect the pull of the Chinese market with the push of locating regional biomedical problems that were marketable to Chinese customers. While I do not uncritically celebrate the discovery of BCT-100 or other Hong Kong biotech inventions, what I hope to illustrate is the salient role of biologist-entrepreneurs in shaping the city's biotech sector.

This article is among the first in East Asian STS scholarship to map Hong Kong's biotech landscape within what Fu Daiwie called the "distinctive East Asian networks" (Fu 2007). To date, Hong Kong has received sparse scholarly interest in the burgeoning East Asian STS scholarship. The standard view regarding biotech in Hong Kong holds that the city had no serious biotech commitment under way in either pre- or posthandover years. Unlike the rest of the Asian Tigers, Hong Kong's colonial government lacked the incentives to invest in new infrastructure in science and technology, whereas the SAR government largely failed in its premillennium biotech institution building. Based on newly collected data, however, I argue that this stereotypical image is beginning to change. In the beginning of this article, I cited the 2012 
Science article as a first glimpse of what I consider to be a changing picture of Hong Kong's biotech sector. With the inauguration of the city's new Innovation and Technology Bureau in November 2015 (Chan 2015), this picture is slowly developing into a more elaborate painting. I am hopeful that the evolving biotech landscape in Hong Kong will attract more dynamic studies from STS scholars in the near future.

\section{References}

American Cancer Society (2016). Cancer in China: More than 7500 Cancer Deaths per Day Estimated. Science Daily 26 January (www.sciencedaily.com/releases/2016/01/160126162209.htm).

Apple Daily 蘋果日報 (2005). Li da chenggong yanfa zhi gan ai yao 理大成功研發治肝癌藥 (PolyU Succeeds in the R\&D of an Anti-liver Cancer Drug). 1 May.

Baark, Erik (2005). Innovation Policy Forensics: An Analysis of Biotechnology in Hong Kong. Paper presented at the DRUID Tenth Anniversary Summer Conference 2005 on Dynamics of Industry and Innovation: Organizations, Networks and Systems, Copenhagen, Denmark, 27-29 June.

Baark, Erik, and Naubahar Sharif (2006). Hong Kong's Innovation System in Transition. In Asia's Innovation Systems in Transition, edited by Bengt-Åke Lundvall, Patarapong Intarakumnerd, and Jan VangLauridsen, 123-47. Cheltenham, UK: Edward Elgar.

BCT Company News (2012). BCT-100, Hong Kong's First Novel Biologic Anti-cancer Drug, Granted IND from US FDA. (www.biocancer.org/view.asp? Id = 1098\&BigClassName $=\% \mathrm{D} 0 \% \mathrm{C} 2 \% \mathrm{CE} \% \mathrm{C} 5 \% \mathrm{D} 6 \%$ D0\%D0\%C4, accessed 10 March 2016).

Berger, Suzanne, and Richard Lester, eds. (1997). Made by Hong Kong. Oxford: Oxford University Press.

Bergeron, Bryan, and Paul Chan (2004). Biotech Industry: A Global, Economic, and Financing Overview. Hoboken, NJ: Wiley.

Capital 資本 (2002). Yu Changhai bianzhi xianggang sheng ke meng 于常海編織香港生科夢 (Albert Yu Weaves Hong Kong's Bioscience Dream). July (www.albertchyu.com.cn/media/report_2011_20.html).

Capital Weekly資本壹週 (2013). Kang da yiliao keji, xianggangren de jiao ao 康達醫療科技, 香港人的驕 傲 (Medical Technology of Bio-Cancer Treatment International Ltd. Is the Pride of Hong Kong People). (www.oncologist.hk/media-detail-1.html, accessed 15 April 2015).

Chan, Margaret (2011). The Worldwide Rise of Chronic Noncommunicable Diseases: A Slow-Motion Catastrophe. Opening Remarks at the First Global Ministerial Conference on Healthy Lifestyles and Noncommunicable Disease Control, Moscow, 28 April. (www.who.int/dg/speeches/2011 /ministerial conf ncd 20110428/en/, accessed 10 March 2016).

Chan, Samuel (2015). Hong Kong's New Innovation and Technology Bureau to Absorb Two Departments from Commerce Bureau. South China Morning Post, 11 November.

Chang, Albert Y. (1999). The Role of Hong Kong SAR in the Development of Biotechnology Industry in China. In Animal Cell Technology: Challenges for the Twenty-First Century, Proceedings of the Joint International Meeting of the Japanese Association for Animal Cell Technology (JAACT) and the European Society for Animal Cell Technology (ESACT) 1998, Kyoto, Japan, edited by Kouji Ikura et al., 1-4. Dordrecht: Kluwer.

Cheng, Paul N., et al. (2007). Pegylated Recombinant Human Arginase (rhArg-peg 5,000 mw) Inhibits the In Vitro and In Vivo Proliferation of Human Hepatocellular Carcinoma through Arginine Depletion. Cancer Research 67, no. 1: 309-17.

Ducor, Phillip (1998). Patenting the Recombinant Products of Biotechnology and Other Molecules. London: Kluwer.

Eastweek 東週刊 (2009). Bao shou tuo fa zhou qi bang ti(kan) zhongliu ke mingyi 暴瘦脫髪周啟邦睇腫瘤 科名醫 (Weight and Hair Loss Led Kai-Pong Chau to See a Famous Oncologist). 10 March.

Economist (2010). Hong Kong's Economy: End of an Experiment. 7 July.

Fisher, Jill (2009). Medical Research for Hire: The Political Economy of Pharmaceutical Clinical Trials. New Brunswick, NJ: Rutgers University Press.

Foster, Peter (2011). Top Ten Chinese Food Scandals. Telegraph, 27 April.

Fu, Daiwie (2007). How Far Can East Asian STS Go? A Position Paper. East Asian Science, Technology and Society 1: 1-14.

Fujimura, Joan (1996). Crafting Science: A Sociohistory of the Quest for the Genetics of Cancer. Cambridge, MA: Harvard University Press. 
Fuller, Douglas B., ed. (2010). Innovation Policy and the Limits of Laissez-Faire: Hong Kong's Policy in Comparative Perspective. Basingstoke: Palgrave Macmillan.

Gelfert, Axel (2013). Before Biopolis: Representations of the Biotechnology Discourse in Singapore. East Asian Science, Technology and Society 7, no. 1: 103-23.

Global Times 環球時報 (2005). Xianggang gan ai xin yao huo guoji jin jiang (xin yao liang xiang) 香港肝癌 新藥獲國際金獎 (新藥亮相) (Hong Kong’s New Anti-liver Cancer Drug Receives International Gold Medal [Debut of a New Drug]). 7 June.

Griffiths, James (2015). Could Tiny Fish Be the Answer to China's Food Safety Woes? This Hong Kong Start-Up Thinks So. South China Morning Post, 13 March.

HKSTP (Hong Kong Science and Technology Park) (2014). Hong Kong Science Park Phase 3 Doubles Partner Companies to Forty-Five. 20 March (www.hkstp.org/en-US/News-Media-Events/Corporate -News/2014/Hong-Kong-Science-Park-Phase-3-Doubles-Partner-Com.aspx, accessed 10 March 2016).

Hong Kong Department of Health (2007). Promoting Health in Hong Kong: A Strategic Framework for Prevention and Control of Non-communicable Disease (www.change4health.gov.hk/en/strategic framework/structure/steering_committee/promoting_health/index.html, accessed 10 March 2016).

Hsueh, Eddy C., et al. (2012). Deprivation of Arginine by Recombinant Human Arginase in Prostate Cancer Cells. Journal of Hematology and Oncology 5, no. 17: 1-6.

Jasanoff, Sheila (2006). Biotechnology and Empire: The Global Power of Seeds and Science. Osiris 21: 273-92.

Kaslow, David, and Joseph Shiloach (1994). Production, Purification and Immunogenicity of a Malaria Transmission-Blocking Vaccine Candidate: TBV25H Expressed in Yeast and Purified using NickelNTA Agarose. Nature Biotechnology 12: 494-99.

Keller, William W., and Richard J. Samuels (2003). Innovation and the Asian Economies. In Crisis and Innovation in Asian Technology, edited by William W. Keller and Richard J. Samuels, 1-22. Cambridge: Cambridge University Press.

Lam, Tin-Lun, et al. (2010). Recombinant Human Arginase Inhibits the In Vitro and In Vivo Proliferation of Human Melanoma by Inducing Cell Cycle Arrest and Apoptosis. Pigment Cell Melanoma Research 24, no. $2: 366-76$.

Liu, Jennifer A. (2012). Asian Regeneration? Technohybridity in Taiwan's Biotech? East Asian Science, Technology and Society 6, no. 3: 401-14.

Lo, Alex (2015). Hong Kong’s Hi-Tech Realty Is More Low End. South China Morning Post, 27 March.

Ma, Allen (2015). Savvy Tech Investors Showing Confidence in Hong Kong. South China Morning Post, 1 April.

MacPhail, Theresa (2014). The Viral Network: A Pathography of the H1N1 Influenza Pandemic. Ithaca, NY: Cornell University Press.

Maienschein, Jane (2014). Embryos under the Microscope: The Divergent Meanings of Life. Cambridge, MA: Harvard University Press.

Mussai, Francis, et al. (2015). Arginine Dependence of Acute Myeloid Leukemia Blast Proliferation: A Novel Therapeutic Target. Blood 125, no. 15: 2386-96.

Nature (2001). Putting the Pieces Together: Hong Kong. 26 July: 4-5.

NIH (National Institutes of Health) (2009). Study of Pegylated Human Recombinant Arginase for Liver Cancer (clinicaltrials.gov/show/NCT00988195, accessed 10 March 2016).

NIH (National Institutes of Health) (2010). Study of Pegylated Human Recombinant Arginase for Liver Cancer (BCT-100-002) (clinicaltrials.gov/ct2/show/study/NCT01092091, accessed 10 March 2016).

Ong, Aihwa (2010). An Analytics of Biotechnology and Ethics at Multiple Scales. In Asian Biotech: Ethics and Communities of Fate, edited by Aihwa Ong and Nancy N. Chen, 1-51. Durham, NC: Duke University Press.

Ong, Aihwa, and Nancy N. Chen (2010). Asian Biotech: Ethics and Communities of Fate. Durham, NC: Duke University Press.

Pisano, Gary (2006). Science Business: The Promise, the Reality, and the Future of Biotech. Cambridge, MA: Harvard University Press.

Rasmussen, Nicolas (2014). Gene Jockeys: Life Science and the Rise of Biotech Enterprise. Baltimore: Johns Hopkins University Press.

Sanders, Sean, ed. (2012). Hong Kong in Focus: Asia's Research Hub. Science 338 (suppl.): 1639-57.

Sharif, Naubahar (2010). Rhetoric of Innovation Policy Making in Hong Kong using the Innovation Systems Conceptual Approach. Science, Technology, and Human Values 35, no. 3: 408-34.

Sing Tao Daily 星島日報 (2012). “Er si ai xibao” gang chan yao guo guan「餓死癌細胞」港產藥過關 (“Starving Cancerous Cells to Death”: A Hong Kong-Manufactured Drug Is Approved). 27 June.

South China Morning Post (2010). Asia’s Biotechnology Hub in the Making. 8 November. 
Steinfeld, Jemimah (2014). Do Chinese Classrooms Need to Talk about Sex? CNN, 19 June (www.cnn.com /2014/06/19/world/asia/china-sex-education/).

Thompson, Charis (2010). Asian Regeneration? Nationalism and Internationalism in Stem Cell Research in South Korea and Singapore. In Asian Biotech: Ethics and Communities of Fate, edited by Aihwa Ong and Nancy N. Chen, 95-117. Durham, NC: Duke University Press.

Tsui-Auch, Lai Si (2000). Functional versus Sectoral Industrial Policy: A Comparative Study of the Biotechnology Development in Hong Kong and Singapore. (citeseerx.ist.psu.edu/viewdoc/download? doi=10.1.1.200.432\&rep=rep1\&type=pdf). Reprinted in Biotechnologie-Globalisierung-Demokratie: Politische Gestaltung transnationaler Technologieentwicklung, edited by Daniel Barben and Gabriele Abels, 251-68. Berlin: Edition Sigma.

UGC (University Grants Committee) (2007a). New Cancer Drug Breakthrough for Hong Kong. Research Frontiers: Newsletter of the Research Grants Council of Hong Kong, China, no. 13 (www.ugc.edu.hk /rgc/rgcnews13/west/03.htm).

UGC (University Grants Committee) (2007b). Gene Mapping Fights “Cantonese” Cancer. Research Frontiers: Newsletter of the Research Grants Council of Hong Kong, China, no. 13 (www.ugc.edu.hk/rgc /rgcnews13/west/06.htm).

Waldby, Catherine (2009). Singapore Biopolis: Bare Life in the City State. East Asian Science, Technology and Society 3: 367-83.

Wee, Joseph T. S., et al. (2010). Is Nasopharyngeal Cancer Really a “Cantonese Cancer”? Chinese Journal of Cancer 29, no. 5: 517-26.

Wong, Joseph (2010). Biotechnology in Hong Kong: Prospects and Challenges. In Innovation Policy and the Limits of Laissez-Faire: Hong Kong's Policy in Comparative Perspective, edited by Douglas Fuller, 221 -41. Basingstoke: Palgrave Macmillan.

Wong, Joseph (2011). Betting on Biotech: Innovation and the Limits of Asia's Developmental State. Ithaca, NY: Cornell University Press.

Yip, Ka-che, ed. (2009). Disease, Colonialism, and the State: Malaria in Modern East Asian History. Hong Kong: University of Hong Kong Press.

Yuan, Robert, and M. Hsu (1995). Hong Kong Looking Forward to 1997. Genetic Engineering News 1 (September): $18-19$.

Zhang, Wen Jie, et al., (2013). The Case for Semi-mandatory HPV Vaccination in China. Nature Biotechnology 31, no. 7: 590-91.

Christine Yi Lai Luk is a postdoctoral fellow at the Hong Kong Institute for the Humanities and Social Sciences at the University of Hong Kong. She received her doctorate from Arizona State University in 2014. This article is an outgrowth of her doctoral research, published as A History of Biophysics in Contemporary China (2015). She is now working on several projects related to the past and present of biophysics, biotech, and biomedicine in modern China. 